\title{
Labour Market Institutions and Income Inequalities in the Visegrad Group Countries
}

\author{
Małgorzata Szczepaniak \\ Ph.D., Department of Economics, Faculty of Economic Sciences and Management \\ Nicolaus Copernicus University in Toruń, Toruń, Poland \\ e-mail:m.szczepaniak@umk.pl
}

\author{
Agnieszka Szulc-Obłoza \\ Ph.D., Department of Human Resource Management, Faculty of Economic \\ Sciences and Management, Nicolaus Copernicus University in Toruń, Toruń, Poland \\ e-mail: aszulc@umk.pl
}

\section{Abstract}

The diversity of the labour market in the Visegrad Group countries is presented in the article from an institutional perspective. Institutions such as different tax and transfer policies, employment protection legislation, or active and passive labour market policies can affect not only the effectiveness of the economy from a macro perspective, but they can also be crucial in determining the system of rules and incentives for earning money. The institutional conditions of the labour market directly affect the behaviour of labour market participants, their incomes, and therefore income inequalities. To asses and compare the situation between the Visegrad group countries, a synthetic measure of labour market institutions is calculated. A taxonomic analysis is done to group the V4 countries against other selected European Union countries, which enables the assessment and comparison of similarities and differences across the Visegrad countries. Finally, the trade-offs between a synthetic measure of labour market institutions and income inequalities are analysed. The Pearson correlation coefficient and, additionally, the Spearman's rank correlation coefficient are applied. The analysis is done for 2016, as it was the most recent data available while writing the article. The results from such an analysis can help to answer the question of the state's role in limiting income inequalities through labour market institutions and to identify the policies which are the most effective in this field.

Keywords: income inequalities, labour market, institutions

JEL: B52, D63, E02, J88, O43 


\section{Introduction}

Income inequalities, which result from uneven development, are considered to be a fundamental issue due to their negative consequences for society. Therefore, it is the state's role to limit inequalities through different policies. Creating labour market conditions seems to be a very crucial issue because it determines the rules for earning money and therefore, income inequalities. Even though a redistribution policy is particularly important in decreasing inequalities, special attention was paid to labour market institutions as the most important institutions.

Members of the state regulate the rules in force on the labour market. In other words, the state creates the environment by defining the instructions, i.e., what is required, prohibited, and permitted on the labour market (Ostrom 2011, p. 17; Ostrom 2005 , p. 17). Additionally, the state funds market intervention, enforces the rules and creates the official authorities. According to North's approach, the rules belong to the institutions (North 1994, p. 2). According to the New Institutional Economics, institutions are a mix of formal (written) and informal constraints (norms, conventions, codes of conduct) (North 2005, p. 1). In this article, only formal rules, such as judicial rules, economic rules and contracts are included (North 1990, p. 47). The national rules laid down by the state must be coherent with EU law and other international rules, such as international conventions.

The aim of the article is to identify the state's role in decreasing income inequalities through labour market institutions. Different groups of labour market institutions (for example, protective labour market institutions, wage settings, systems of taxation and social insurance, or active and passive labour market policies) are analysed in the context of income inequalities. What is more, two measures of income inequalities are taken into consideration: Gini calculated on market income, and disposable income. We also analysed the differences between the Visegrad Group countries ${ }^{1}$, both in terms of labour market institutions as well as income inequalities. We then compared them to the situation across selected countries of the European Union ${ }^{2}$. Finally, the questions which the article tries to answer are: Are the differences in income inequalities connected to labour market institutions? Are the V4 countries a homogenous group that takes into consideration those criteria in comparison with other European Union countries?

To evaluate and compare labour market institutions, a synthetic measure of labour market institutions is provided. A taxonomic analysis is done to group the V4 countries against other European Union countries. Finally, the trade-offs between the synthetic measure of labour market institutions and income inequalities are analysed. The Pearson correlation coefficient and, additionally, Spearman's rank correlation coefficient

1 We use V4 abbreviation for Visegrad Group countries in the article. V4 consistis of: Czech Republic, Slovakia, Poland and Hungary.

2 Because of data availability we chose the European Union countries which were members of OECD in 2016 and use the abbreviation OECD-UE (22) in the article. 
were applied. The important advantage of our research is the institutional perspective used to characterise labour market conditions and the synthetic measure approach. What is more, two income inequality perspectives are considered: Gini calculated on market income and disposable income. This allows us to broaden the analysis to the interrelationships between labour market policies and redistribution policies.

The results of such analysis can help answer the question of the state's role in limiting the income inequalities through labour market institutions and to identify the policies which are most effective in this field.

\section{Relationships between the state's role and income inequalities - a literature review}

The relationships between labour market institutions and inequality are complex. There is no single explanation as to the role of the state in decreasing inequalities through labour market institutions.

On the one hand, a growing body of analysis provides evidence about the negative impact of labour market institutions on inequalities. However, few of them present the theoretical institutional perspective, where it is proved that the state, as the entity that influences the rules on the market, significantly affects both the labour market determinants directly, but also income inequalities (Szczepaniak, Szulc-Obłoza 2019). The majority of opinions are consistent with the neo-classical theory of economics, according to which active labour market policies result in a more elastic labour market and increased employment. However, they can also contribute to higher income inequality. However, on the other hand, some labour market institutions, like passive labour market policies or employment protection legislation, may reduce inequalities (Burniaux et al. 2006). Therefore at least two perspectives can be distinguished in the analysis of these trade-offs: the employee's or employer's perspective, and the flexibility or protection criterion.

The same labour market institutions can have an ambiguous influence on income inequalities. Such dual effects on income inequalities can be observed when employment protective labour market policies are taken into consideration. If employees are more protected, employment protective labour market policies can have a negative impact on wage dispersion and thus decrease inequalities. The impact of institutions occurs both through compressing the wage differential and a higher labour share (Checchi, Garcia-Penalosa 2008). Moreover, redistributive policies embedded in unemployment benefits decrease income inequalities (Checchi, Garcia-Penalosa 2010).

By contrast, the same institutions may increase unemployment directly or through an increase in the tax rate in the future, ultimately increasing income inequalities (Koeniger et al. 2004). From this perspective, if employees are less protected by employment protective labour market policies, the institutions of the labour market can increase inequalities because they reduce participation in the labour force and result 
in an increase in taxes needed to finance unemployment benefits (Burniaux, Padrini, Brandt 2006; Berg 2015). Hence, the more flexible the labour market, the higher the unemployment rates, and the tendency to increase overall inequality by affecting the number of individuals with low incomes (Acemoglu 2003).

The majority of studies have concluded that the relationships between labour market institutions and income inequalities are negligible and depended on social group. For example, the lack of significance of the relationships between tax wedges and union density rate and inequalities is discussed by Checci and Garcia-Penalosa (Checci, Garcia-Penalosa 2010). Thus, even though different characteristics of labour market institutions have been considered, there were no synthetic measures analysed in relation to inequalities, which is the aim of this article.

\section{Income inequalities in the V4 countries}

Many countries, including the V4 countries, have seen rising inequalities over the past three decades. The Czech Republic, Hungary, Poland, and Slovakia comprise the group which successfully transitioned from centrally planned to market economies in the 1990s and joined the European Union in 2004. The effective transformation of these economies was based on institutional reforms which affected the labour market and income inequalities. Even though the state influence was radically weakened in favour of market liberalisations, it was economic policy (e.g., tax, transfers, education, family labour market) that helped alleviate the impact on the population. The unemployment benefits system, and family and child allowances, etc., provided financial protection for the most vulnerable citizens.

Nevertheless, the patterns of income inequalities and conditions on the labour market vary across these countries. The Czech Republic and Slovakia had lower inequalities at the beginning of the 1990s than Poland and Hungary. The Gini index in 1992 was about 23 in the Czech Republic and 22 in Slovakia. In Poland and Hungary, however, it was higher -29 and 28, respectively (OECD 2018a). About 25 years after the transformation, the Gini index in Slovakia and the Czech Republic is about 25 and about 29 in Poland and Hungary. However, much of this rise is connected to the widening dispersion in labour income. That is why the analysis of labour market institutions and the investigation of the relations between these institutions and income inequalities can be valuable as a direction for the state's redistributive policy.

Income inequalities differ widely when two Gini measures (Gini calculated based on market income and Gini calculated based on disposable income) are taken into consideration. The difference (Gini gap) between these measures reflects the state's role in decreasing inequalities through different kinds of policies.

The inequality of income before taxes and transfer is wider in comparison to the inequality of disposable income. It shows that the state's interference through taxes and 
transfers reduces inequality in all countries, but the extent to which the state's policy effectively decreases the Gini index differs across countries. What is important to notice is that income dispersion mainly reflects labour market income, which is shaped by differences in regulations on the labour market (Figure 1). Nevertheless, total market income (including capital income and self-employment) is more concentrated than when only labour income is taken into consideration (OECD 2012).
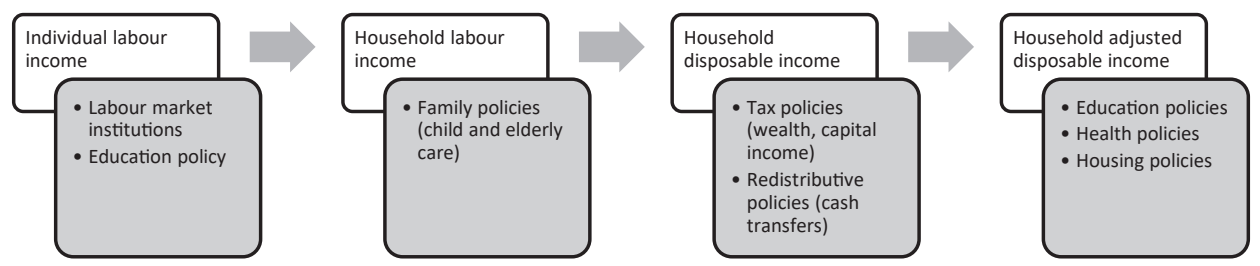

Figure 1. Income concepts and relevant state policies used to evaluate the inequalities Source: own elaboration based on OECD 2012.

Table 1. Market income and disposable income inequalities in V4 countries and OECD-EU average; Gini gaps and rankings in 2016

\begin{tabular}{|l|c|c|c|c|c|c|c|}
\hline \multicolumn{1}{|c|}{ Country } & $\begin{array}{c}\text { Gini } \\
\text { market } \\
\text { income }\end{array}$ & $\begin{array}{c}\text { Ranking } \\
\text { (Gini market } \\
\text { income) }\end{array}$ & $\begin{array}{c}\text { Gini } \\
\text { disposable } \\
\text { income }\end{array}$ & $\begin{array}{c}\text { Ranking } \\
\text { (Gini } \\
\text { disposable } \\
\text { income) }\end{array}$ & $\begin{array}{c}\text { Change } \\
\text { in ranking }\end{array}$ & $\begin{array}{c}\text { Gini } \\
\text { Gap }\end{array}$ & $\begin{array}{c}\text { Ranking } \\
\text { Gini Gap }\end{array}$ \\
\hline Slovakia & 40.2 & 1 & 25.1 & 2 & -1 & 15.1 & 20 \\
\hline Hungary & 45.5 & 5 & 28.8 & 9 & -4 & 16.7 & 15 \\
\hline Poland & 45.5 & 6 & 29.2 & 11 & -5 & 16.3 & 16 \\
\hline Czech Republic & 46.0 & 8 & 25.8 & 3 & +5 & 20.2 & 10 \\
\hline $\begin{array}{l}\text { Average } \\
\text { in OECD } \\
- \text { European } \\
\text { countries (22) }\end{array}$ & 48.7 & & 29.5 & & & 19.2 & \\
\hline
\end{tabular}

Source: own elaboration based on OECD 2018a.

When analysing the income inequalities, the Gini calculated on disposable income is taken into consideration because it is the income after transfers and taxes that determines the consumption. Nevertheless, market income inequalities and disposable income inequalities were compared to show the role of state "effectiveness" in decreasing inequalities in each country.

Inequalities in income after taxes and transfers in each of the V4 countries, as measured by the Gini disposable income index, were lower than in OECD-EU(22) countries, and they were, on average, about $63 \%$ lower than inequalities in income before taxes and transfers in 2016. The Gini index after taxes and transfers ranged from 25 in Slovenia and Slovakia to 35 in Latvia. The Gini index before taxes and transfers ranged from 40.2 in Slovakia to 56.6 in Greece. In each V4 country, both indices were lower than in the OECD, on average (Table 1). 
Slovakia was characterised both by inequality originating from market income and disposable income far below the OECD-European (22) average. The tax and transfers institutions are reducing household disposable income inequality far below the OECD average in the Czech Republic and Slovakia, while Hungary and Poland are characterised as being close to the OECD-EU average. Hungary, Poland, and the Czech Republic were characterised by inequality originating from the labour market that was close to but slightly below the OECD-EU average. It seems that cash transfers and taxes tend to have a smaller redistributive impact in Poland and Hungary. That is why inequalities in household disposable income are higher in Poland and Hungary than in the Czech Republic and Slovakia and close to the OECD-EU average (OECD 2012). Additionally, the only country in the $\mathrm{V} 4$ group which is improving its position in the ranking is the Czech Republic, which takes $3^{\text {rd }}$ place instead of $8^{\text {th }}$ in the ranking when disposable income is included in the analysis. This improvement is connected with the Czech Republic's Gini gap, which is slightly higher than the OECD-EU(22) average and much higher than the Gini gaps in Slovakia, Hungary and Poland.

\section{Methods}

The need to analyse whole sets of institutions is highlighted in the literature (Betcherman 2013, p. 2; Horwath, Szalai 2008). Identifying and analysing a sophisticated set of institutions remains a challenge because of the complexity of the institutions, the continuous changes in the institutions themselves, and additionally their mutual interactions (Batcherman 2013; Horwath, Szalai 2008; Gaweł, Klimczak 2005). The following may be included in the institutions which affect the demand as well as the supply side of the labour market: protective labour market institutions (rules for employing and dismissing), wage-setting system, taxes, rules of active contribution, passive labour market policies (LMPs) and labour market policy services (Table 2) (Higgins, Pica 2017; Woźniak-Jęchorek 2015; Horwath, Szalai 2008; Wiśniewski 1999). Institutions of active LMPs cover interventions such as training, employment incentives, supported employment and rehabilitation, direct job creation, and start-up incentives. In turn, the institutions of passive labour market policies include out-of-work income maintenance or support and early retirement. LMP services cover all activities of the Public Employment Services for jobseekers (Eurostat 2018, https://ec.europa.eu/euros tat/cache/metadata/fr/lmp_esms.htm) (accessed: 15.10.2018).

The V4 were ranked in order with selected European Union countries on the basis of the synthetic measure of labour market institutions in 2016. The following elements were included in the synthetic measure of labour market institutions, due to data availability: hiring and firing regulations (Fraser Institute ${ }^{3}$ ), centralised collective bargaining (Fraser Institute ${ }^{1}$ ), hours regulations (Fraser Institute ${ }^{1}$ ), mandated cost of worker

3 Only data for 2015 are available. 
dismissal (Fraser Institute ${ }^{1}$ ), the ratio of minimum wage to value-added per worker (Doing Business), active labour market policy expenditures (Eurostat), passive labour market policy expenditures (Eurostat), labour market services expenditures (Eurostat), tax revenue paid by employees (OECD), tax revenue paid by employers (OECD), taxes on the incomes of individuals (OECD) and tax wedge (OECD). The Fraser Institute, as one of the main sources of data in the analysis, provided information with a delay. As a result, because the data from 2016 were the latest available, the research was done for that year. Diagnostic variable selection is based on substantive and statistical criteria (Zeliaś 2000). The diagnostic set of data is characterised by a low level of similarity (the variability coefficient which exceeds the threshold value of $10 \%$ ) and low correlation among each other (the Pearson correlation coefficient is not more than 0.8 ) (Zeliaś 2000). Characteristics considered to be destimulants are modified into stimulants using the following transformation:

Table 2. Set of labour market institutions

\section{Elements}

1. Protective labour market institutions - employment protection legislation indicator (EPL)

\section{Wage-setting system}

- minimum wage

- union density

- union coverage

- wage bargaining coordination

\section{System of taxation and social insurance}

- income tax

- tax wedge

- social contributions paid by employer and employees

4. Institutions of active labour market policies (LMP 2-7)

- ALMP expenditure in percentage of GDP

- ALMP expenditure per unemployed people in percent of GDP per capita

5. Institutions of passive labour market policies (LMP 8-9)

- PLMP expenditure in percentage of GDP

6. Labour market services (LMP 1)

- LMP services expenditure in percentage of GDP

Source: own analysis based on Horwath, Szalai 2008.

$$
x_{i k}=\frac{1}{x_{i k}^{D}}
$$

where:

$x_{i k}$ - value of feature transformed into a stimulant,

$i-i$-th object $(i=1, \ldots, \mathrm{N})$,

$x_{i k}^{D}$ - value of the $k$-th feature which is a destimulant.

In the next stage, the normalisation of final diagnostic variables by dividing each value by the range is applied: 


$$
z_{i k}=\frac{x_{i k}-x_{k \min }}{x_{k \max }-x_{k \min }}
$$

where:

$x_{i k}$ - value of the $k$-th feature in the $i$-th object,

$z_{i k}$-value of the normalised $k$-th feature in the $i$-th object (Zeliaś 2000; Kolenda 2006),

$x_{k \min }, x_{k \max }-$ minimum and maximum value of the $k$-th feature.

The synthetic measure of diagnostic variables is achieved by calculating the mean of the final diagnostic variables for every country (Zeliaś 2000). Another possibility for the characterisation of labour market institutions as the set of rules is provided by the Employment Protection Legislation Index, the Index of Economic Freedom, and Labour Market Efficiency (OECD 2018b; Heritage Foundation 2018a; The World Bank 2018).

Additionally, selected European Union countries, including the Visegrad Group, were grouped. In order to group the objects by measure of the labour market institution, Ward's Method was applied (Mirkin 2005; Everitt et al. 2011). By using Ward's Method, the aim was to combine countries into clusters so that the variance within the clusters was minimised (Ward's minimum variance method).

To measure the dependence between the synthetic measure of institutions and inequality, the Pearson correlation coefficient and, additionally, Spearman's rank correlation coefficient were applied. The Gini coefficients calculated based on market income and disposable income as measures of inequality were used. Additionally, to evaluate the state's role in the intervention into inequalities, the Gini Gap was included. Microsoft Excel and R system were used for statistical computation and graphics.

\section{Results of the analysis}

The sorted sequence of 22 countries according to the estimated synthetic measure of labour market institution variables was prepared (Table 3).

The synthetic measure of labour market institutions ranged from 0.22 in the United Kingdom to 0.61 in France 4 . The United Kingdom and Ireland are characterised by the least regulated (most elastic) labour market according to synthetic measures. By contrast, France, Austria, Finland, and Belgium are the countries with the most regulated labour markets and the most protected employees. The Czech Republic, Poland and Slovakia were alike - relatively elastic when labour market institutions are considered. Hungary was distinguished from other V4 countries (Table 4). The employees were more protected in Hungary, but at a level near the OECD-UE average.

4 The more the labour market is regulated (the more the employee is protected), the higher the value of the synthetic measure of labour market institutions. 
Table 3. Synthetic measure of institutional variables in selected European Union countries in 2016

\begin{tabular}{|c|l|c|c|l|c|}
\hline Rank & \multicolumn{1}{|c|}{ Country } & $\begin{array}{c}\text { The synthetic } \\
\text { measure of labour } \\
\text { market institutions }\end{array}$ & Rank & \multicolumn{1}{c|}{ Country } & $\begin{array}{c}\text { The synthetic } \\
\text { measure of labour } \\
\text { market institutions }\end{array}$ \\
\hline 1 & United Kingdom & 0.22 & 12 & Hungary & 0.38 \\
\hline 2 & Ireland & 0.23 & 13 & Portugal & 0.38 \\
\hline 3 & Latvia & 0.24 & 14 & Netherlands & 0.39 \\
\hline 4 & Czech Republic & 0.28 & 15 & Slovenia & 0.40 \\
\hline 5 & Poland & 0.29 & 16 & Spain & 0.44 \\
\hline 6 & Slovakia & 0.30 & 17 & Italy & 0.44 \\
\hline 7 & Estonia & 0.31 & 18 & Germany & 0.47 \\
\hline 8 & Denmark & 0.35 & 19 & Belgium & 0.51 \\
\hline 9 & Luxembourg & 0.35 & 20 & Finland & 0.51 \\
\hline 10 & Sweden & 0.37 & 21 & Austria & 0.53 \\
\hline 11 & Greece & 0.38 & 22 & France & 0.61 \\
\hline
\end{tabular}

Source: own calculations.

Table 4. Ranking of Visegrad countries according to the selected indices

\begin{tabular}{|l|c|c|c|c|c|c|c|}
\hline & \multirow{2}{*}{$\begin{array}{c}\text { The } \\
\text { synthetic } \\
\text { measure }\end{array}$} & \multirow{2}{*}{$\begin{array}{c}\text { Labour } \\
\text { free- } \\
\text { of labour } \\
\text { market in- } \\
\text { stitutions }\end{array}$} & $\begin{array}{c}\text { Labour } \\
\text { market } \\
\text { efficiency }\end{array}$ & $\begin{array}{c}\text { Individual } \\
\text { and collec- } \\
\text { tive dismiss- } \\
\text { als (regular } \\
\text { contracts) }\end{array}$ & $\begin{array}{c}\text { Sndividual } \\
\text { dismissals } \\
\text { (regular } \\
\text { contracts) }\end{array}$ & $\begin{array}{c}\text { Tem- } \\
\text { porary } \\
\text { con- } \\
\text { tracts }\end{array}$ & $\begin{array}{c}\text { Collective } \\
\text { dismissals } \\
\text { (additional } \\
\text { restrictions) }\end{array}$ \\
\hline $\begin{array}{l}\text { Czech } \\
\text { Republic }\end{array}$ & 4 & 2 & 13 & 13 & 21 & 10 & 3 \\
\hline Hungary & 12 & 7 & 16 & 4 & 2 & 9 & 18 \\
\hline Poland & 5 & 10 & 17 & 9 & 11 & 12 & 7 \\
\hline Slovakia & 6 & 13 & 20 & 6 & 5 & 15 & 13 \\
\hline
\end{tabular}

Source: OECD 2018b; Heritage Foundation 2018b; World Economic Forum 2018.

Visegrad countries were classified in different positions, depending on the indices considered, and the components included in the indices influence the country's place in the ranking (Table 4). For example, labour freedom included the ratio of the minimum wage to the average value added per worker, hindrance in hiring additional workers, the rigidity of hours, the difficulty of firing redundant employees, legally mandated notice period, and mandatory severance pay (Heritage Foundation 2018b). Slovakia was classified as the last country from the V4 countries regarding both labour freedom as well as labour market efficiency. In turn, labour market efficiency covers redundancy costs, hiring and firing practices, cooperation in labour-employer relations, the flexibility of wage determination, the ease of finding skilled employees, the ease of hiring foreign labour, active labour market policies, pay and productivity, reliance on professional management, female participation in the labour force, male participation in the labour force, and salary tax wedge (World Economic Forum 2018). 
The indicators of employment protection legislation measure the procedures and costs involved in dismissing individuals or groups of workers as well as the procedures involved in hiring workers on fixed-term or temporary work agency contracts (OECD 2018b). Just one component can influence the overall value of the index, and the consequences are observable in country rankings. For example, Hungary is distinguished by the scale of active labour market policy, which is included as a component of the estimated synthetic measure of labour market institutions. The consequence is observed in the last place it achieved within the group of Visegrad countries, the $12^{\text {th }}$ place among 22 countries (Table 4). In turn, according to the World Economic Forum, Slovakia's restrictive labour market regulations are identified as one of the most problematic factors for doing business there (World Economic Forum 2016). Hence, the position within labour market efficiency is one of the lowest (Table 4).

As a result, the next step of our analysis divided the countries into eight groups by Ward's method. The Visegrad countries were classified into two groups. The Czech Republic and Slovakia, together with Latvia, were in the first group, while Hungary and Poland, together with Slovenia, Greece, Portugal, and Luxembourg were in the second group (Figure 2).

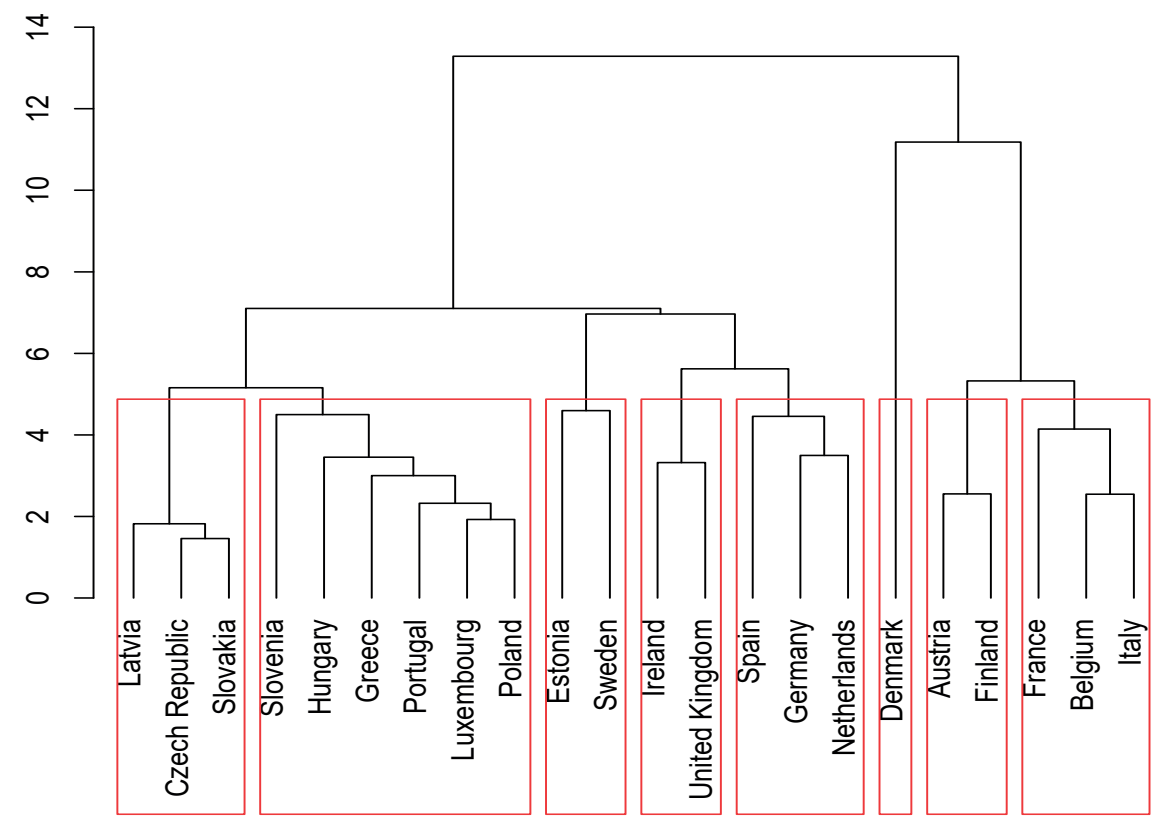

Figure 2. Dendrogram - groups of countries in 2016 Source: own elaboration.

The first group, i.e., the Czech Republic, Slovakia, and Latvia, was characterised by a very low tax burden (the Czech Republic and Slovakia are the lowest in OECD-UE 22), an average tax wedge, very elastic/flexible labour market policies services, elastic/ 
flexible active labour market policies and very elastic/flexible passive labour market policies. Protective labour market institutions, especially in the aspect of centralized collective bargaining, were relatively elastic in this group of countries.

The second group (Hungary, Poland, Slovenia, Greece, Portugal and Luxembourg) was characterized by lower than average taxes on the income of individuals but a relatively high tax burden connected with employees' social security contributions. Hungary was unique in this group. It can be described by the most elastic/flexible passive labour market policies, the most protective active LMPs, and one of the highest tax wedges among all OECD-UE (22).

The third group (Estonia and Sweden) was characterized by a relatively high employer social security contribution tax burden. Moreover, in the ranking, Estonia and Sweden were with countries with a synthetic measure at an average level depreciated by standard deviation.

The fourth group (Ireland and the United Kingdom) is very characteristic because of the very elastic labour market institutions, the low level of employee protection, and the extremely low tax wedge. Additionally, according to the synthetic measure of labour market institutions that was built, these countries were at the very top of the ranking.

The fifth group (Spain, Germany, and the Netherlands) is characterised by a relatively high tax wedge and moderate protective labour market regulations. The differences in this group appear when labour market institutions are analysed. Active and passive labour market institutions are relatively elastic in Germany, while passive labour market institutions that are relatively protective for workers were identified in the Netherlands and Spain. The synthetic measure of labour market institutions in these countries was at an average level.

Denmark is characterized by such special labour market conditions that it is the only country in the sixth group. The lack of minimum wage regulations, the very elastic wage-setting system and elastic protective labour market regulations were identified, along with very protective active labour market policies. The tax system is also very special because a relatively very high tax burden and no social security contributions were identified. In other words, flexicurity is the distinguishing element. The combination of the flexible labour market, generous social security and an active labour-market policy with rights and obligations for the unemployed are characteristic elements for flexicurity.

The seventh group consists of Austria and Finland, which are characterized by very protective passive labour market regulations and relatively protective active labour market regulations. Tax burden and tax wedge are relatively high. Austria was second-last on the ranking of countries according to synthetic measure of labour market institutions, and Finland placed third-last.

The eighth group (France, Belgium, and Italy) was characterised by a highly regulated EPL (especially hiring and firing regulations, centralised collective bargaining), and also setting wages (in the aspect of minimum wage); high active and passive LMPs 
but relatively low employee social security contributions; high employer social security contributions and high individual income tax burden; and a high tax wedge.

The highest market income inequalities are identified in the group containing Ireland and the United Kingdom, where employees are the least protected. Additionally, the highest average Gini Gap results in transfers and taxes being highly effective in decreasing inequalities, and finally lower inequalities after taxes and transfers than in groups 2, 3, 5, and 7. The Czech Republic, Slovakia, and Latvia are characterised by the lowest average Gini market income and a very low Gini Gap, and one of the lowest averages of inequalities after taxes and transfers. Poland and Hungary, together with the rest of the countries from the second group, are characterised by a moderate average Gini market income and Gini Gap, but a relatively high average Gini disposable income (Table 5).

Table 5. Average Gini disposable income, market income, and Gini gap in country groups in 2016

\begin{tabular}{|c|c|c|c|}
\hline $\begin{array}{c}\text { Groups } \\
\text { of countries }\end{array}$ & $\begin{array}{c}\text { Average Gini disposable } \\
\text { income }\end{array}$ & $\begin{array}{c}\text { Average Gini } \\
\text { market income }\end{array}$ & $\begin{array}{c}\text { Average } \\
\text { Gini gap }\end{array}$ \\
\hline 1 & 28.5 & 44.50 & 16.00 \\
\hline 2 & 30.2 & 48.93 & 18.73 \\
\hline 3 & 30.4 & 45.15 & 14.75 \\
\hline 4 & 29.6 & 53.25 & 23.60 \\
\hline 5 & 30.9 & 49.17 & 18.30 \\
\hline 6 & 26.3 & 45.10 & 18.80 \\
\hline 7 & 29.9 & 51.33 & 21.47 \\
\hline 8 & 26.8 & 50.10 & 23.35 \\
\hline
\end{tabular}

Source: own elaboration.

As the last step of the analysis, correlation coefficients were calculated to identify the relationships between labour market institutions and income inequalities. The Pearson coefficient calculations showed that there were weak or no relations between the synthetic measure of labour market institutions and the Gini index (before and after taxes and transfers) in 2016. It was 0.23 (not significant, $\mathrm{p}=0.34$ ) and -0.15 (not significant, $\mathrm{p}=0.51$ ), respectively. Furthermore, the results of the Pearson correlation coefficient and Spearman's rank correlation coefficient were comparable, 0.19 (not significant, $\mathrm{p}=0,45$ ) and -0.13 (not significant, $\mathrm{p}=0.45$ ), respectively. The signs of the correlation coefficients between the Gini market income and the labour income institutions were positive (the more regulated the labour market, the higher the income before taxes and transfers inequalities). When state policy (taxes and transfers) is taken into consideration, the more regulated the labour market, the lower the income after taxes and transfers inequalities. But the results cannot prove a strong relation.

The strongest but still weak positive relation 0.38 (significant, $\mathrm{p}=0.08$ ) was identified between the synthetic measure of the labour market institutions and the Gini Gap. The higher the synthetic measure of the labour market institutions, the more regulated the labour market/the more protected the employees, the higher the Gini Gap. It can be in- 
terpreted that state policy through transfers and taxes is more effective in decreasing inequalities when the labour market institutions protect employees to a great extent.

\section{Conclusion}

Our analysis allowed us to compare the situation on the labour market from an institutional perspective, compare the income inequalities, and present the relationships between labour market institutions and income inequalities from an institutional perspective.

Comparing two inequalities measures, i.e., Gini calculated on the basis of market income and disposable income, allowed us to evaluate the role of the state from the perspective of distributional policy. It confirmed that state policy, through taxes and transfers, decreases the inequalities to a different extent. Market income inequalities were lowest in Slovakia among the V4 group. Transfers and taxes tend to have a smaller redistributive impact in Poland and Hungary than in the Czech Republic and Slovakia. Inequalities in household disposable income are higher in Poland and Hungary than in the Czech Republic and Slovakia, and they are close to the OECD-EU average (OECD 2012). The Gini gap was much higher in the Czech Republic than in Slovakia, Hungary and Poland. That is why disposable income inequalities are the lowest in Slovakia and the Czech Republic in the V4 group.

Labour market institutions were estimated through a synthetic measure which was calculated for each country. Hungary stood out when analysing the estimated synthetic measure of labour market institutions. The Czech Republic, Poland and Slovakia were ranked one after the other. The position of the V4 was influenced by the components of the index analysed. There were changes of up to 11 places - in the case of the Czech Republic regarding labour freedom and labour market efficiency. Labour market efficiency is a more sophisticated index, in which more components are included than in labour freedom. For example, differences in the situation on the labour market between sexes are included. Hence, the critical element is the methodology of estimating the particular index.

In the literature, the challenge of including the diverse range of labour market institutions is highlighted. The variety of data that characterised the labour market institutions was determined by the year of the analysis. Removing information from the Fraser Institute would enable us to include 2017 in the analysis, but it would simultaneously reduce the group of analysed institutions. Moreover, due to the relative stability of the rules, huge changes between particular countries are not observed over time. Additionally, it is worth highlighting that labour market institutions are only part of the institutional framework in which activities are executed. That is the argument for analysing inequalities and institutions from different angles.

Additionally, a taxonomic analysis of the group the V4 countries against other selected European Union countries was carried out. The Czech Republic with Slovakia were classified in one group, while Poland and Hungary were classified in another. 
The analysis showed the diversity of the V4 countries both from the perspective of labour market institutions as well as income inequalities. The Czech Republic and Slovakia provided more flexible active and passive labour market policies than both Poland and Hungary. However, Hungary stood out in terms of the highest tax wedge and the most protective active labour market policies.

The V4 countries were not homogenous from the income inequalities perspective. Disposable income inequalities were one of the lowest (also in comparison the EU countries) in Czech Republic and Slovakia. However, when market income inequalities are considered, the situation changes drastically.

The results of the analysis are consistent with the literature, and they show weak relationships between labour market institutions and income inequalities, particularly if the difference between market and disposable income inequalities was considered. It means that the more regulated the labour market, the greater the redistributional policies decrease income inequalities.

In conclusion, the different approaches in measuring income inequalities may affect the results of the analysis of relationships between uneven income distribution and labour market institutions. However, from the institutional perspective, as used in this article, in both cases, it is the state which plays an important role in shaping the rules.

\section{References}

Acemoglu, D. (2003), Cross-country Inequality, "The Economic Journal”, 113. https:// doi.org/10.1111/1468-0297.00100

Berg, J. (2015), Labour market institutions: the building blocks of just societies, Labour Markets, Institutions and Inequality Building Just Societies in the $21^{\text {st }}$ Century, International Labour Office, Geneva, Switzerland.

Betcherman, G. (2013), Labour Market Institutions: A Review of the Literature, World Development Report, World Bank.

Burniaux, J., Padrini, F., Brandt, N. (2006), Labour Market Performance, Income Inequality and Poverty in OECD Countries, OECD Economic Department Working Papers No. 500, OECD, Paris.

Checchi, D., García-Peñalosa, C. (2008), Labour market institutions and income inequality, "LIS Working Paper Series", 470, Luxembourg Income Study (LIS), Luxembourg. https://doi.org/10.1111/j.1468-0327.2008.00209.x

Checchi, D., Garcia-Peñalosa, C. (2010), Labour Market Institutions and the Personal Distribution of Income in OECD Countries, "IZA Discussion Paper", 1681. https:// doi.org/10.1111/j.1468-0335.2009.00776.x

Eurostat (2018), https://ec.europa.eu/eurostat/cache/metadata/fr/lmp_esms.htm (accessed: 15.10.2018).

Everitt, B., Landau, S., Leese, M., Stahl, D. (2011), Cluster analysis, Wiley. https://doi .org/10.1002/9780470977811

Gaweł, T., Klimczak, M. (2005), Pojęcie instytucji w prawie i ekonomii, "Economics and Law", 1 (1). 
Heritage Foundation (2018a), https://www.heritage.org/index/pdf/2018/book/metho dology.pdf (accessed: 15.10.2018).

Heritage Foundation (2018b), https://www.heritage.org/index/labor-freedom (accessed: 15.10.2018).

Higgins, N., Pica, G. (2017), Complementarities between labour market institutions and their causal impact on youth labour market outcomes, "Employment Working Paper", 224, International Labour Office.

Horwath, H., Szalai, Z. (2008), Labour market institutions in Hungary with a focus on wage and employment flexibility, "Occasional Papers 77”, Magyar Nemzeti Bank.

Koeniger, W., Leonardi, M., Nunziata, L. (2004), Labour Market Institutions and Wage Inequality, "IZA Discussion Paper”, 1291.

Kolenda, M. (2006), Taksonomia numeryczna, Klasyfikacja, porządkowanie i analiza obiektów wielocechowych, Wydawnictwo Akademii Ekonomicznej we Wrocławiu.

Mirkin, B. (2005), Clustering for Data Mining: A Data Recovery Approach, Chapman \& Hall/CRC Computer Science \& Data Analysis, PB CRC Press.

North, D.C. (1994), Institutional Change: A Framework of Analysis, Economic History.

North, D.C. (2005), Understanding the Process of Economic Change, Princeton University Press, Princeton.

OECD (2012), Income inequality and growth: The role of taxes and transfers, OECD Economics Department Policy Notes, No. 9. January 2012.

OECD (2018a), Income Distribution Database, https://stats.oecd.org/Index.aspx?Data SetCode= IDD (accessed: 5.10.2018).

OECD (2018b), Employment Protection Legislation: Strictness of employment protection legislation: regular employment, OECD Employment and Labour Market Statistics (database) (accessed: 5.10.2018).

Ostrom, E. (2005), Understanding Institutional Diversity, Princeton University Press, Princeton. https://doi.org/10.1515/9781400831739

Ostrom, E. (2011), Background on the Institutional Analysis and Development Framework, “The Policy Studies Journal”, 39 (1). https://doi.org/10.1111/j.1541-0072.2010 .00394.x

Szczepaniak, M., Szulc-Obłoza, A. (2019), Labour Market Institutions and Income Inequalities across the European Union, "Economics and Law", 18 (3). https://doi .org/10.12775/EiP.2019.025

The World Bank (2018), Labour Market Efficiency, TCdata 360, https://tcdata360.wor ldbank.org/indicators/lbr.mkt.efcy?country=BRA\&indicator=737\&viz=line_char t\&years $=2007,2017 \#$ (accessed: 7.10.2018).

Wiśniewski, Z. (1999), Kierunki i skutki deregulacji rynku pracy w krajach Unii Europejskiej, Wydawnictwo Uniwersytetu Mikołaja Kopernika, Toruń.

World Economic Forum (2016), The Global Competitiveness Report 2016-2017, Geneva.

World Economic Forum (2018), http://reports.weforum.org/global-competitiveness-re port-2015-2016/appendix-a-measurement-of-key-concepts-and-preliminary-index -structure/ (accessed: 19.10.2018).

Zeliaś, A. (ed.) (2000), Taksonomiczna analiza przestrzennego zróżnicowania poziomu życia w Polsce w ujęciu dynamicznym, Wydawnictwo AE, Kraków. 


\section{Streszczenie}

\section{Instytucje rynku pracy i nierówności dochodowe w krajach grupy wyszehradzkiej}

W artykule przedstawiono różnorodność rynku pracy w krajach Grupy Wyszehradzkiej z perspektywy ekonomii instytucjonalnej. Instytucje takie jak: regulacje w zakresie podatków i transferów, przepisy dotyczące ochrony zatrudnienia lub aktywna i pasywna polityka rynku pracy mogą wpływać nie tylko na efektywność gospodarki z perspektywy makroekonomicznej, ale również odgrywać kluczową rolę w określaniu systemu zasad i zachęt do zarabiania pieniędzy. W tej perspektywie warunki instytucjonalne rynku pracy bezpośrednio wpływają na zachowanie uczestników rynku pracy, ich dochody, a tym samym nierówności dochodowe.

W celu dokonania oceny i porównania sytuacji między krajami Grupy Wyszehradzkiej, obliczono syntetyczną miarę instytucji rynku pracy. Ponadto przeprowadzono analizę taksonomiczną, w efekcie której pogrupowano kraje V4 względem wybranych krajów Unii Europejskiej. Takie działanie umożliwiło ocenę i porównanie podobieństw i różnic między krajami wyszehradzkimi. Finalnie podjęto próbę identyfikacji i oceny związków między syntetyczną miarą instytucji rynku pracy a nierównościami dochodowymi. Zastosowano współczynnik korelacji Pearsona i dodatkowo współczynnik korelacji rang Spearmana.

Wyniki analizy są próbą odpowiedzi na pytanie o rolę państwa w ograniczaniu nierówności dochodowych za pomocą instytucji rynku pracy i pomagają zidentyfikować te działania, które są najbardziej skuteczne w analizowanej dziedzinie.

Słowa kluczowe: instytucje, nierówności dochodowe, rynek pracy 